\title{
MEDIA PEMBELAJARAN BERBASIS WEB MATA PELAJARAN IPA KELAS VII
}

\author{
Darman \\ Pendidikan Teknologi Informasi FKIP Universitas Muhammadiyah Kendari \\ Email: darman@umkendari.ac.id
}

\begin{abstract}
Abstrak
Penelitian ini bertujuan untuk mendesain media pembelajaran berbasis web mata pelajaran ipa terpadu kelas VII di SMPN 10 Kendari. Metode yang digunakan dalam penelitian ini adalah Research and Defelopment yang terdiri dari 3 Tahap yaitu: Tahap Studi Pendahuluan, Tahap Studi Pengembangan, dan Tahap Evaluasi. Hasil dari penelitian ini adalah media pembelajaran yang telah diuji kelayakannya. Dari hasil uji kelayakan konten mendapat nilai sebesar 94,32 \%, hasil penilaian validasi materi sebesar 94,44\%, hasil penilaian uji kelayakan kelompok kecil/terbatas sebesar 87,92 \%, dan hasil penilaian uji kelayakan kelompok besar/kelompok lebih luas sebesar 86,03\%, Secara keseluruhan Media pembelajaran berbasis web mata pelajaran ipa terpadu di SMPN 10 Kendari sangat layak digunakan dalam pembelajaran.
\end{abstract}

Kata Kunci: Media Pembelajaran berbasis web

\begin{abstract}
This study aims to design a web-based learning media integrated science class VII subjects at SMPN 10 Kendari. The method used in this research is Research and Development which consists of 3 Phases, namely: Preliminary Study Phase, Development Study Phase, and Evaluation Phase. The results of this study are learning media that have been tested for eligibility. From the results of the feasibility test the content got a value of $94.32 \%$, the results of the assessment of material validation were $94.44 \%$, the results of the assessment of the feasibility test for small / limited groups were $87.92 \%$, and the results of the assessment of the feasibility test of large groups / wider groups were 86,03\%, Overall Web-based learning media integrated science subjects in SMPN 10 Kendari is very suitable for use in learning.
\end{abstract}

Keywords: Web-based Learning Media, Integrated IPA. 


\section{PENDAhUluAN}

Era transformasi pendidikan abad ke-21 merupakan arus perubahan dimana guru dan siswa akan sama-sama memainkan peranan penting dalam kegiatan pembelajaran. Peran guru bukan hanya sebagai trasfer of knowledge atau guru merupakan satu-satunya sumber belajar yang bisa melakukan apa saja (teacher center), melainkan guru sebagai mediator dan fasilitator aktif untuk mengembangkan potensi aktif siswa yang ada pada dirinya. Dalam pembelajaran media berperan penting dalam meningkatkan pengetahuan siswa, salah satunya adalah media pembelajaran berbasis web.

Pembelajaran berbasis web merupakan sebuah media pembelajaran yang sangat bermanfaat dalam melakukan pembelajaran. Media pembelajaran berbasis web adalah proses belajar mengajar yang dilakukan dengan memanfaatkan jaringan internet atau intranet. Dengan pembelajaran web ini diharapkan mampu untuk membantu guru dan peserta didik untuk mencapai pembelajaran yang maksimal. Dalam keterkaitan dengan fungsi media pembelajaran dapat ditekankan beberapa hal yaitu: sebagai alat bantu dalam proses pembelajaran, Sebagai pengarah dalam pembelajaran, sebagai komponen dari subsistem pembelajaran, pembangkit perhatian dan motivasi siswa, menigkatkan hasil dan proses pembelajaran, mengurangi terjadinya verbalisme, dan mengatasi terbatasnya ruang dan waktu. Perancangan media pembelajaran berbasis web meliputi: studi pendahuluan dengan megindentifikasi kebutuhan dan karekteristik siswa, pengembangan model, dan evaluasi.

Ipa terpadu merupakan salah satu mata pelajaran di Sekolah Menengah Pertama (SMP) yang terdiri dari gabungan beberapa bidang ilmu seperti fisika, biologi, dan kimia. Media pembelajaran berbasis web ipa terpadu merupkan aplikasi berbasis web yang dapat dioperasikan pada laptop atau komputer yang dikemas dengan menggunakan flas disk (FD).

Media pembelajaran berbasis web merupakan media yang digunakan dalam proses pembelajaran dengan menggunakan jaringan internet maupun intranet. Media pembelajaran berbasis web ini atau yang dikenal dengan "web based learning" merupakan salah satu jenis penerapan dari pembelajaran elektronik. Pembelajaran berbasis web mempunyai karakteristik adalah 1) Interaktivity, 2) Independency, 3) Accesbility, dan 4) Enrichmen. 
Penggunaan media pembelajaran berbasis web akan memberikan pengalaman belajar dan keterampilan baru bagi siswa. Ada tiga tingkatan utama modus belajar yang dikemukakan oleh Burner yaitu: pengalaman lansung, pengalaman gambar, dan pengalaman abstrak. Proses pembelajaran akan berhasil dengan baik apabila siswa dapat memanfaatkan semua panca inderanya. Perbandingan perolehan hasil belajar melalui indera pandang dan indera dengan sangat menonjol perbedaanya. Kurang lebih $80 \%$ hasil belajar sesorang diperoleh memalui indera pandang, dan hanya 15\% diperoleh melalui indera dengan, dan 5\% lagi diperoleh dari indera lainnya.

Media pembelajaran berbasis web memiliki dampak yang cukup positif terhadap pembelajaran. Media pembeajaran bukan hanya sebagai alat tepapi harus memiliki nilai-nilai yang dapat mengembangkan kemampuan soft skills maupun hard skills. Secara utuh media pembelajaran memiliki nilai sebagai berikut: 1) menjadikan konsep yang abstrak menjadi konkret, sehingga mudah dipahami oleh siswa, 2) tidak membawa objek berbahaya, bias digantikan dengan gambar, animasi, simulaasi, foto atau model, 3) memperjelas objek pesan, 4) berinteraksi dengan lingkungan, 5) menimbulkan motivasi, kreaktivitas, dan inovatif siswa, 6)seragamnya pengamatan, dan focus lebih jelas dan 7) mengontrol arah dan kecepatan belajar siswa.

\section{METODE PENELITIAN}

\subsection{Jenis Penelitian}

Jenis penelitian yang digunakan adalah Research and Defelopment $(R \& D)$. yaitu metode penelitian yang digunakan untuk menghasilkan produk tertentu dan menguji kelayakan produk teresebut. Model Penelitian R \& D dengan mengadopsi model yang dikembangkan oleh Sugiono (2010) yakni yang terdiri dari 3 Tahap yaitu: Tahap Studi Pendahuluan, Tahap Studi Pengembangan, dan Tahap Evaluasi. Tahapan kegiatan penelitian Media Pembelajaran Berbasis Web Mata Pelajaran Ipa Terpadu Kelas VII Di SMP Negeri 10 Kendari adalah sebagai berikut: 


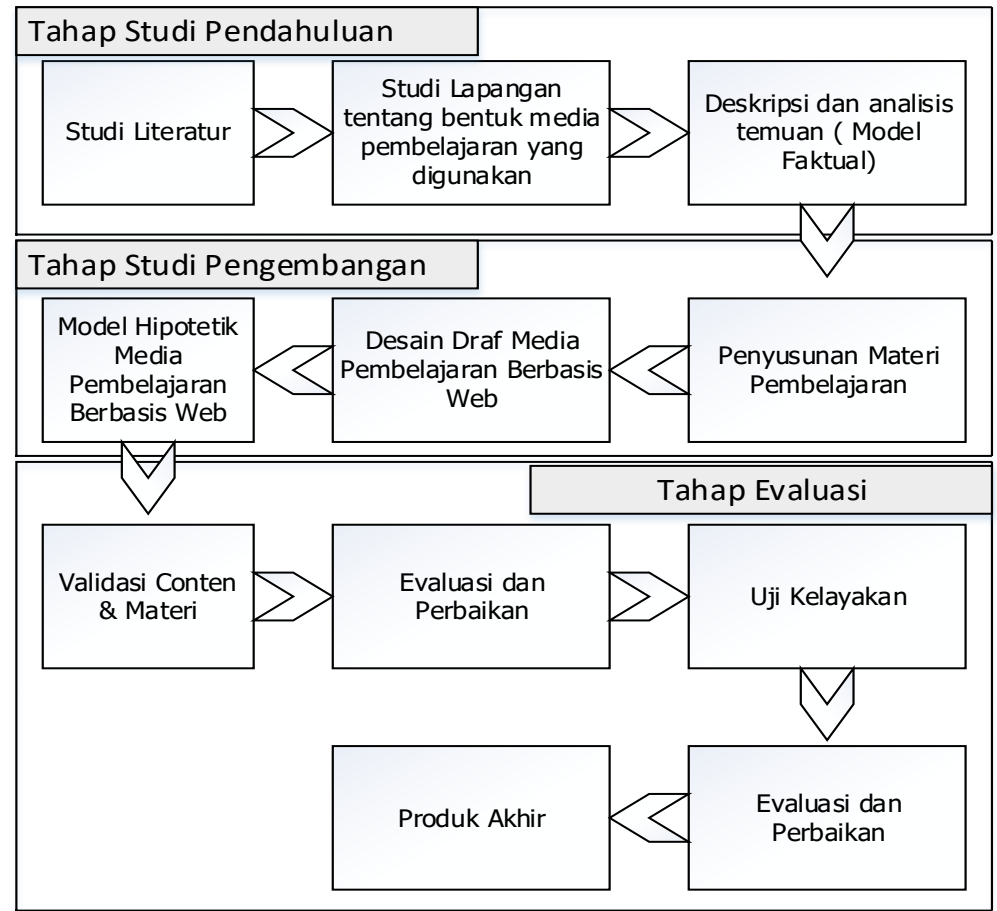

Gambar 2.1. Tahap Kegiatan Penelitian dan Pengembangan Media Pembelajaran Berbasis Web Mata Pelajaran Ipa Terpadu Kelas VII Di SMP Negeri 10 Kendari

\subsection{Teknik Pengumpulan Data}

Teknik pengumpulan data yang digunakan adalah Observasi, Dokumentasi, dan Instrumen.

\subsubsection{Observasi}

Observasi awal proses pembelajaran IPA Terpadu didapat pembelajaran sudah menggunakan perangkat teknologi informasi namun masuh sebatas dalam bentuk power point, media semacam ini pembelajaran masih terpusat saman guru, siswa hanya sebagai penerima informasi.

\subsubsection{Dokumentasi}

Dokumentasi dalam penelitian ini dilakukan dengan mengumpulkan data-data awal atau mengumpulkan sumber-sumber tertulis seperti Silabus, RPP, Materi pembelajaran serta bukubuku paket yang digunakan dalam pembelajaran, selain itu digunakan untuk mendokumentasikan pada saat validasi dan uji kelayakan. 


\subsubsection{Instrumen}

Instrumen digunakan untuk mengukur kelayakan media pembelajaran dalam validasi dan uji kelayakan berupa uji coba terbatas dan uji lebih luas.

\subsection{Teknik Analisis Data}

Teknik analisis data yang digunakan adalah teknik analisis deskriptif. Dengan memaparkan hasil validasi dan hasil uji kelayakan. Data yang terkumpul diproses dengan cara dijumlahkan, dibandingkan dengan jumlah yang diharapkan dan diperoleh presentase (Arikunto, 1996), atau dapat ditulis dengan rumus:

$$
\text { Persentase Kelayakan }(\%)=\frac{\text { Skor yang diobservasi }}{\text { Skor yang diharapkan }} X 100 \%
$$

Setelah penyajian dalam bentuk presentase, Data tersebut diinterprestasikan guna memudahkan dalam pengambilan kesimpulan.

Tabel 2. 1. Tabel skala persentase menurut Arikunto (1996)

\begin{tabular}{|c|c|}
\hline Persentase Pencapaia & Interpretasi \\
\hline $76-100 \%$ & Sangat Layak \\
\hline $56-75 \%$ & Layak \\
\hline $40-55 \%$ & Tidak Layak \\
\hline $0-39 \%$ & Sangat Tidak Layak \\
\hline
\end{tabular}

\subsection{Hasil Penelitian}

\section{HASIL PENELITIAN}

\subsubsection{Hasil Desain Media}

Media Pembelajaran Berbasis Web Mata Pelajaran Ipa Terpadu Kelas VII Di SMP Negeri 10 Kendari, setelah mengalami beberapa revisi maka tampilan yang dihasilkan adalah sebagai berikut: 
Jurnal: Inovasi Sains dan Teknologi (INSTEK)

ISSN: 2655-0563, Edisi: Vol 2, No 2, Agustus 2019
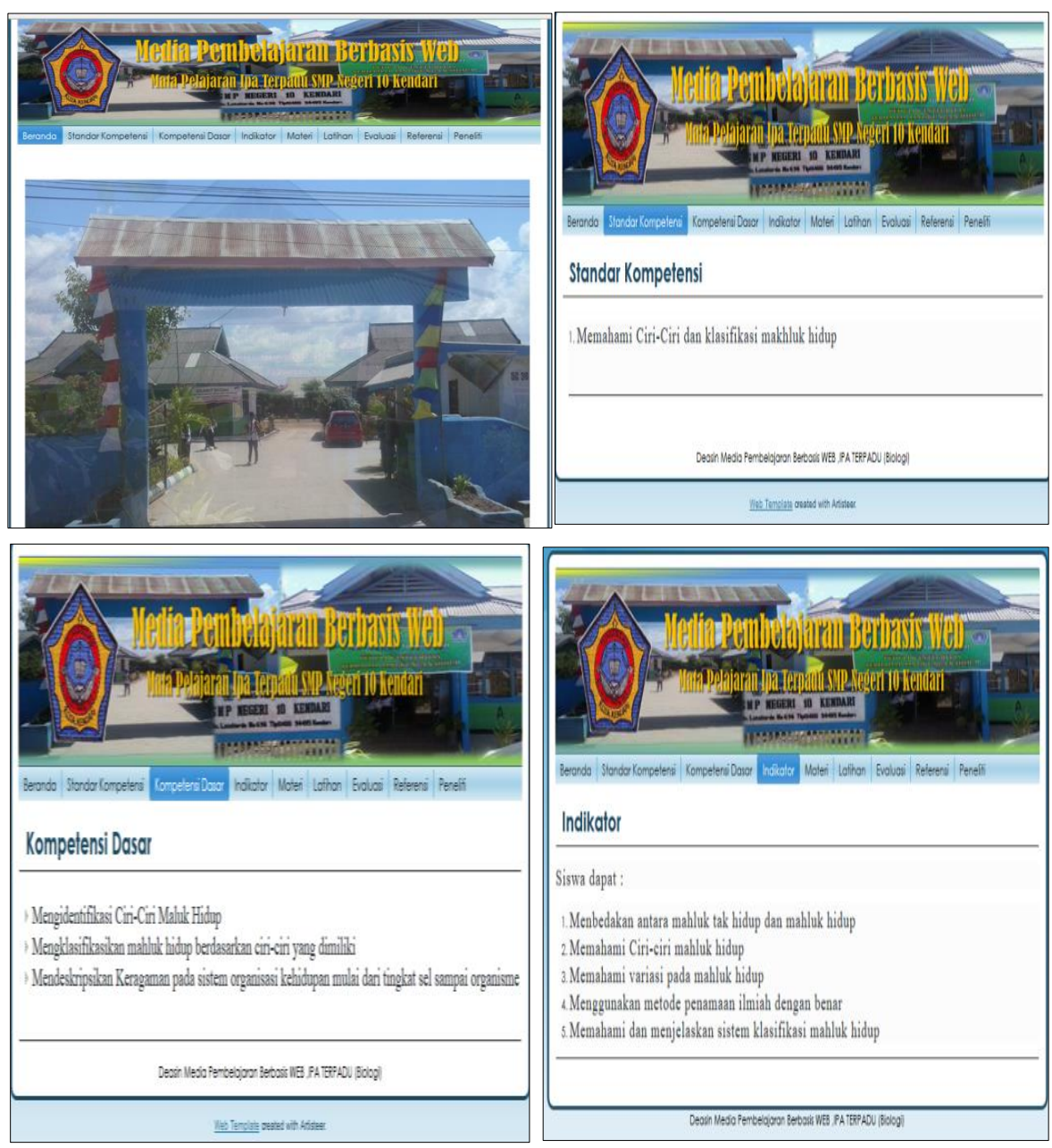

Gambar 3.1. Tampilan Beranda, Standar Kompetensi, Kompetensi Dasar, Indikator 
Jurnal: Inovasi Sains dan Teknologi (INSTEK)

ISSN: 2655-0563, Edisi: Vol 2, No 2, Agustus 2019

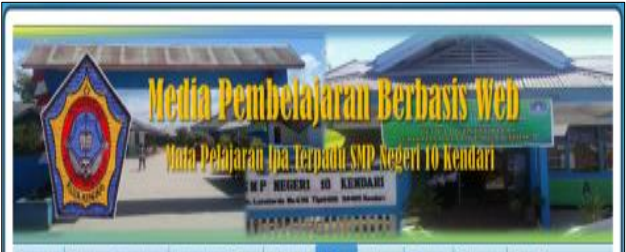

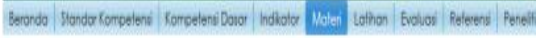

A. Ciri-Ciri Makhluk Hidup

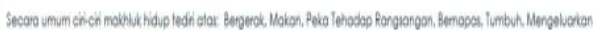

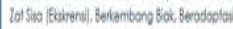

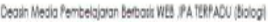

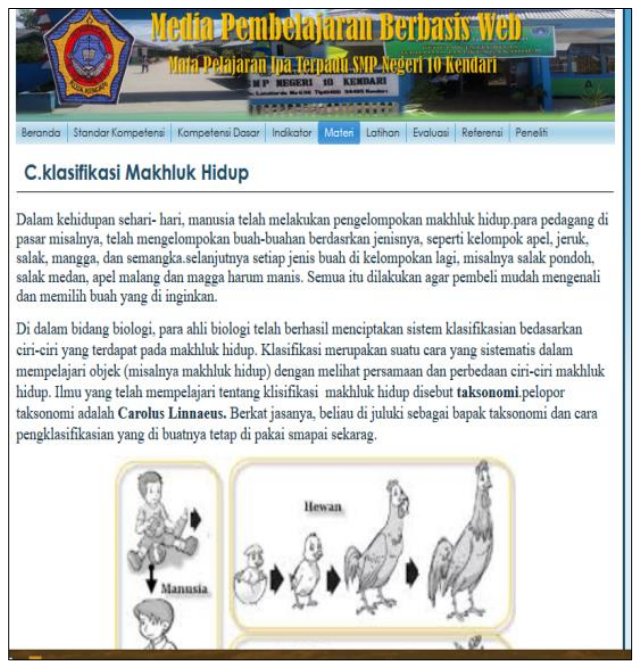

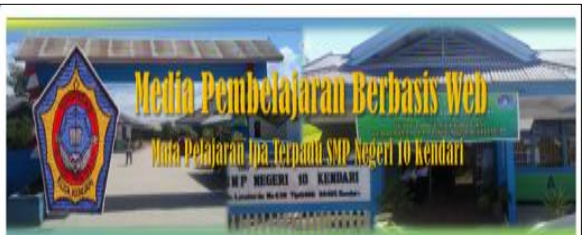

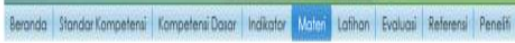

CIRI-CIRI DAN KLASTFIKASI MAKHLUK HIDUP

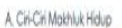

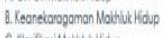

C. Corikei Hothuk Hidup

D. Periembangan Sistem Karitloi

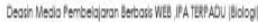

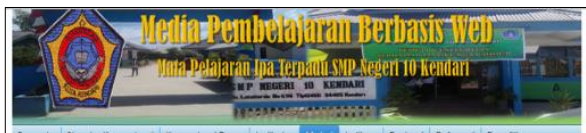

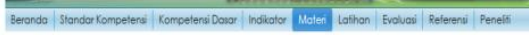

B. Keanekaragaman Makhluk Hidup

Perbedaaan yang terjadi di antara individu sejenis disebut variasi. Di dunia ini, tidak pernah di jumpai dua individu yang identik sama, baik ukuran tubuh, warma kulit, berat badan, bentuk hidung. Karena makhluk hidup begitu beragam, maka kita memerlukakn pengelompokan (klasifikasi) untuk memudahkan mempelajari makhluk hidup.

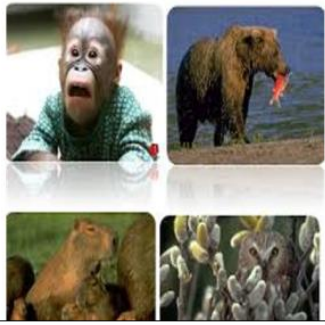

Gambar 3.2. Tampilan Halaman Materi
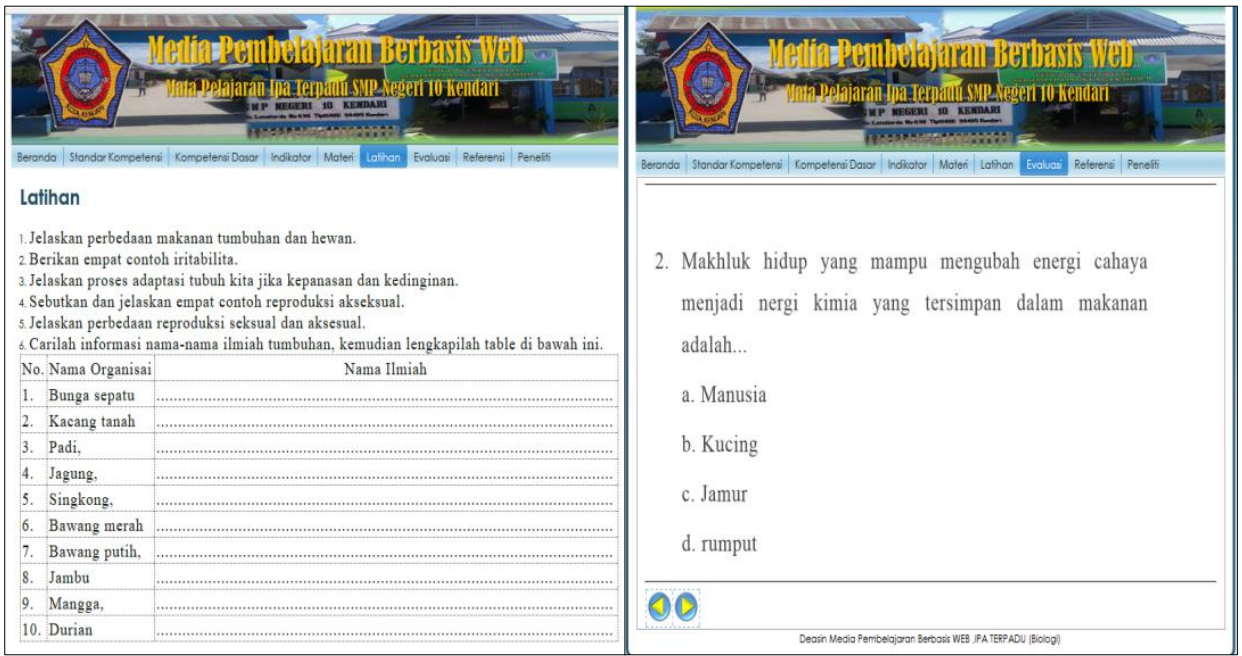

Gambar 3.3. Tampilan Halaman Latihan dan Evaluasi 


\subsubsection{Hasil Validasi}

Setelah media pembelajaran berbasis web didesain maka dilakukan validasi, yaitu validasi konten dan validasi materi pembelajaran. Validasi konten dilakukan guna untuk mengetahui keterhubungan konten yang dibangun setiap page atau halaman, dan validasi materi berguna untuk mengetahun kesesuaian materi yang ada dalam media pembelajaran berbasis web dengan materi yang diajarkan disekolah.

\subsubsection{Validasi Konten}

Aspek penilaian validasi konten ditinjau dari beberapa aspek yaitu: 1) aspek komunikasi, 2) aspek desain teknis, 3) urutan penyajian. Hasil validasi konten dapat dilihat pada tebel 3.1.

Tabel 3.1. Hasil Validasi Konten

\begin{tabular}{|r|l|c|c|c|c|}
\hline No. & \multicolumn{1}{|c|}{$\begin{array}{c}\text { Aspek } \\
\text { Penilaian }\end{array}$} & $\begin{array}{c}\text { Skor } \\
\text { Observasi }\end{array}$ & $\begin{array}{r}\text { Skor Yang } \\
\text { diharapkan }\end{array}$ & $\begin{array}{r}\text { Kelaya } \\
\text { kan (\%) }\end{array}$ & Ket \\
\hline 1. & Komunikasi & 76 & 80 & 95 & $\begin{array}{l}\text { Sangat } \\
\text { layak }\end{array}$ \\
\hline 2. & Desain Teknis & 62 & 64 & 96,88 & $\begin{array}{l}\text { Sangat } \\
\text { layak }\end{array}$ \\
\hline 3. & $\begin{array}{l}\text { Urutan } \\
\text { Penyajian }\end{array}$ & 28 & 32 & 87,50 & $\begin{array}{l}\text { Sangat } \\
\text { layak }\end{array}$ \\
\hline & Jumlah & 166 & 176 & 94,32 & $\begin{array}{l}\text { Sangat } \\
\text { layak }\end{array}$ \\
\hline
\end{tabular}

Bila digambarkan dalam bentuk diagram batang adalah sebagai berikut:

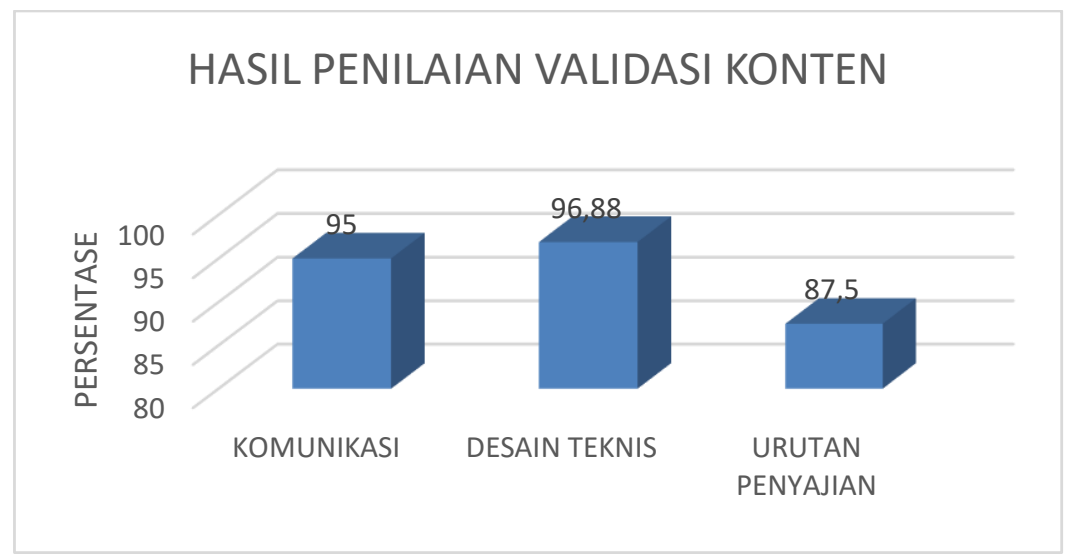

Gambar 3.4. Diagram Batang Hasil Validasi Konten 


\subsubsection{Validasi Materi}

Aspek penilaian validasi materi ditinjau dari aspek 1) isi materi, 2) strategi pembelajaran. Hasil validasi materi dapat dilihat pada table 3.2.

Tabel 3.2. Validasi Materi

\begin{tabular}{|r|l|c|c|c|c|}
\hline No. & $\begin{array}{c}\text { Aspek } \\
\text { Penilaian }\end{array}$ & $\begin{array}{c}\text { Skor } \\
\text { Observasi }\end{array}$ & $\begin{array}{c}\text { Skor Yang } \\
\text { diharapkan }\end{array}$ & $\begin{array}{c}\text { Kelayakan } \\
(\%)\end{array}$ & Ket \\
\hline 1. & Isi Materi & 105 & 112 & 93,75 & $\begin{array}{c}\text { Sangat } \\
\text { Layak }\end{array}$ \\
\hline 2. & $\begin{array}{l}\text { Strategi } \\
\text { pembelajaran }\end{array}$ & 31 & 32 & 96,88 & $\begin{array}{c}\text { Sangat } \\
\text { Layak }\end{array}$ \\
\hline & Jumlah & 136 & 144 & 94,44 & \\
\hline
\end{tabular}

Bila digambarkan dalam bentuk diagram batang adalah sebagai berikut:

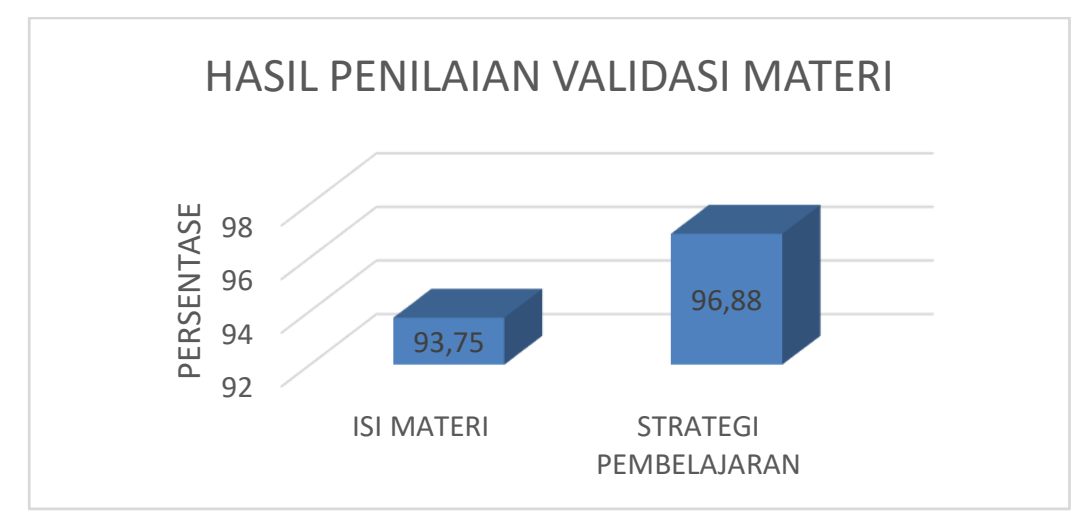

Gambar 3.5. Diagram Batang Hasil Validasi Materi

\subsubsection{Hasil Uji Kelayakan}

\subsubsection{Uji Kelompok Kecil}

Aspek penilaian uji kelayakan kelompok kecil untuk siswa meliputi: 1) Efek strategi pembelajaran, 2) Komunikasi, 3) Desain teknis. Uji kelayakan kelompok kecil dilakukan untuk mendapatkan masukan dari calon pengguna. Responden kelayakan kelompok kecil diambil secara acak sebanyak 6 orang siswa/siswa SMPN 10 Kendari Kelas VII yang mempelajari mata pelajaran ipa terpadu. Hasil dari uji kelayakan kelompok kecil disajikan pada tabel 3.3. 
Tabel 3.3. Hasil Uji Kelayakan Kelompok Kecil

\begin{tabular}{|l|l|c|c|c|l|}
\hline No. & \multicolumn{1}{|c|}{$\begin{array}{c}\text { Aspek } \\
\text { Penilaian }\end{array}$} & $\begin{array}{c}\text { Skor } \\
\text { Observasi }\end{array}$ & $\begin{array}{c}\text { Skor Yang } \\
\text { diharapkan }\end{array}$ & $\begin{array}{c}\text { Kelayakan } \\
(\%)\end{array}$ & \multicolumn{1}{|c|}{ Ket } \\
\hline 1. & $\begin{array}{l}\text { Efek Strateg } \\
\text { Pembelajaran }\end{array}$ & 85 & 96 & 88,54 & $\begin{array}{l}\text { Sangat } \\
\text { Layak }\end{array}$ \\
\hline 2. & Komunikasi & 64 & 72 & 88,89 & $\begin{array}{l}\text { Sangat } \\
\text { layak }\end{array}$ \\
\hline 3. & $\begin{array}{l}\text { Desain } \\
\text { Teknis }\end{array}$ & 62 & 72 & 86,11 & $\begin{array}{l}\text { Sangat } \\
\text { layak }\end{array}$ \\
\hline & Jumlah & 211 & 240 & 87,92 & $\begin{array}{l}\text { Sangat } \\
\text { layak }\end{array}$ \\
\hline
\end{tabular}

Bila digambarkan dalam bentuk diagram batang adalah sebagai berikut:

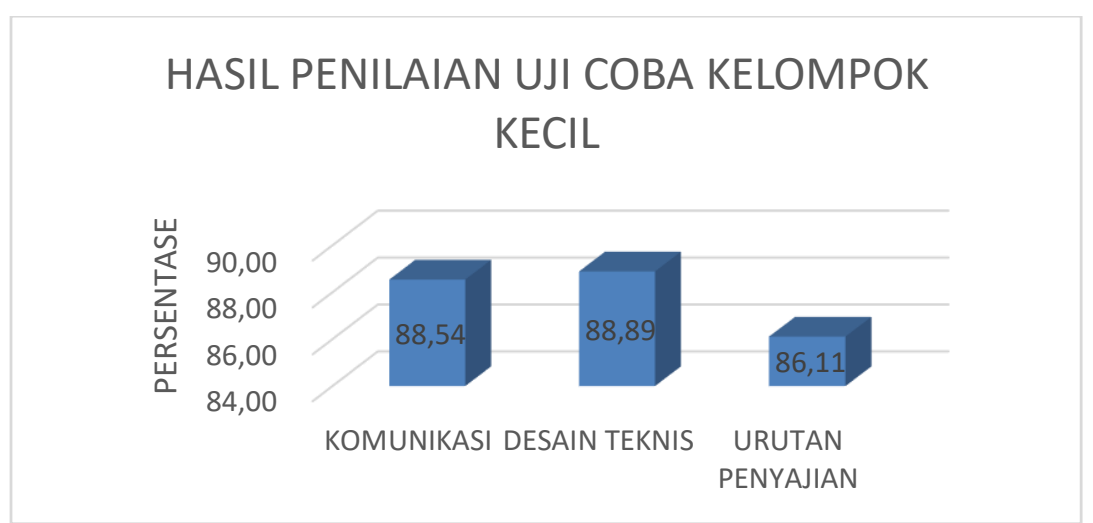

Gambar 3.6. Diagram Batang Hasil Validasi Uji Kelompok Kecil

\subsubsection{Uji Kelompok Besar}

Aspek penilaian uji kelompok besar untuk siswa meliputi: 1) Efek strategi pembelajaran, 2) Komunikasi, 3) Desain teknis. Uji uji kelompok besar dilakukan untuk mendapatkan masukan dari calon pengguna. Respondeng uji kelompok kecil diambil secara acak sebanyak 29 orang siswa/siswa SMPN 10 Kendari Kelas VII yang mempelajari mata pelajaran ipa terpadu. Hasil dari uji uji kelompok besar disajikan pada tabel 3.4. 
Tabel 3.4. Hasil Uji Kelayakan Kelompok Besar

\begin{tabular}{|l|l|c|c|c|c|}
\hline No. & \multicolumn{1}{|c|}{$\begin{array}{c}\text { Aspek } \\
\text { Penilaian }\end{array}$} & $\begin{array}{c}\text { Skor } \\
\text { Observasi }\end{array}$ & $\begin{array}{c}\text { Skor Yang } \\
\text { diharapkan }\end{array}$ & $\begin{array}{c}\text { Kelayakan } \\
(\%)\end{array}$ & Ket \\
\hline 1. & $\begin{array}{l}\text { Efek Strateg } \\
\text { Pembelajaran }\end{array}$ & 400 & 464 & 86,21 & $\begin{array}{l}\text { Sangat } \\
\text { Layak }\end{array}$ \\
\hline 2. & Komunikasi & 302 & 348 & 86,78 & $\begin{array}{l}\text { Sangat } \\
\text { layak }\end{array}$ \\
\hline 3. & $\begin{array}{l}\text { Desain } \\
\text { Teknis }\end{array}$ & 296 & 348 & 85,05 & $\begin{array}{l}\text { Sangat } \\
\text { layak }\end{array}$ \\
\hline & Jumlah & 998 & 1160 & 86,03 & $\begin{array}{l}\text { Sangat } \\
\text { layak }\end{array}$ \\
\hline
\end{tabular}

Bila digambarkan dalam bentuk diagram batang adalah sebagai berikut:

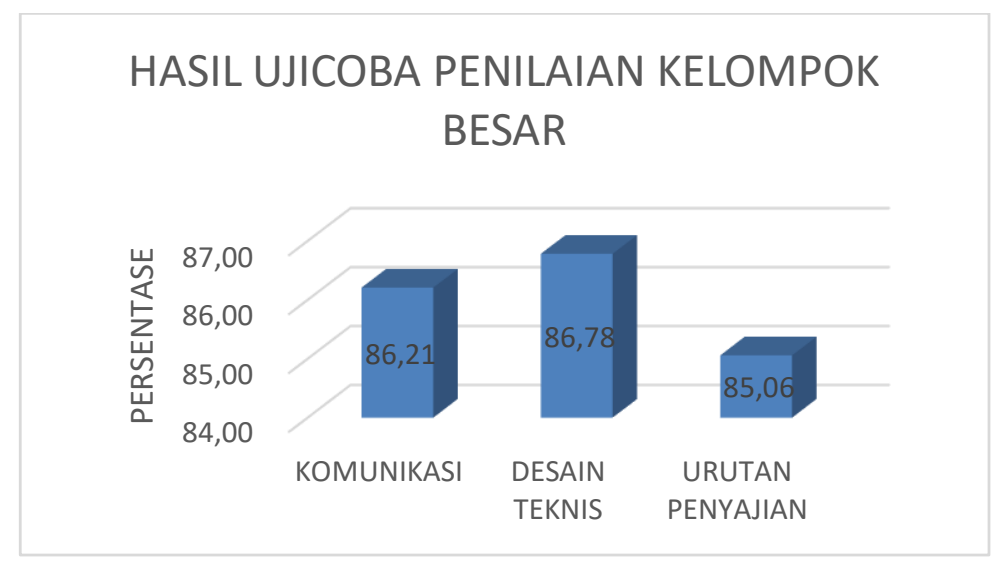

Gambar 3.7. Diagram Batang Hasil Validasi Uji Kelompok Besar

\subsection{Pembahasan Hasil Penelitian}

Validasi konten media pembelajaran berbasis web mata pelajaran ipa terpadu di SMPN 10 Kendari dengan melibatkan 4 orang yang berlatar belakan pendidikan magister sistem informai dan diperoleh hasil sebagai berikut : dari aspek komunikasi yang terdiri dari kemudahan mulai program, logika, berpikir, interaksi dengan pengguna, kejelasan petunjuk penggunaan dan penggunaan bahasa memperoleh nilai $95 \%$, dari aspek Desain teknis Terdiri dari format teks, penggunaan warna, kualitas gambar dan pengguna tombol interaktif memperoleh nilai $96,88 \%$ sedangkan urutan penyajian yang terdiri atas transisi antar halaman dan tampilan program memperoleh nilai 87,50 \%. Secara keseluruhan, hasil Validasi konten media pembelajaran berbasis web mata pelajaran ipa terpadu di SMPN 10 Kendari sebesar 94,32 $\%$ sesuai dengan tabel 2.1 skala 94,32 \% berada tingkat yang sangat layak, sehingga tingkat 
validasi konten media pembelajaran berbasis web mata pelajaran ipa terpadu di SMPN 10 Kendari di interpretasikan sangat layak digunakan.

Hasil Validasi materi media pembelajaran berbasis web mata pelajaran ipa terpadu di SMPN 10 Kendari yang melibatkan 4 orang guru mata pelajaran ipa terpadu yang ditinjau dari isi materi yang terdiri dari kesesuaian dengan SAP, relevensi dengan kemampuan siswa, kejelasan topik pembelajaran, materi sulit dipahami, keruntutan materi, cakupan materi, relevansi gambar dan ilustarsi dengan materi memperoleh nilai $93,75 \%$, dan strategi pembelajaran terdiri dari kemudahan penggunaan dan kemudahan memahami materi, memperoleh nilai 96,88\%. Secara keseluruhan, hasil penilaian validasi materi pada media pembelajaran berbasis web mata pelajaran ipa terpadu di SMPN 10 Kendari sebesar 94,44 \%, sesuai dengan tabel 2.1. Skala 94,44 $\%$ berada pada tingkat yang sangat layak, sehingga tingkat validasi materi pada media pembelajaran berbasis web mata pelajaran ipa terpadu di SMPN 10 Kendari di SMPN 10 Kendari di interprestasikan sangat layak digunakan.

Hasil penilaian uji kelayakan kelompok terbatas/kelompok kecil media pembelajaran berbasis web mata pelajaran ipa terpadu di SMPN 10 Kendari dengan melibatkan 6 (enam) orang siswa ditinjau dari aspek efek strategi pembelajaran yang terdiri dari menambah pengetahuan siswa, kemudahan penggunaan, meningkatkan rasa ingin tahu siswa, dan kejelasan materi yang disajikan memperoleh nilai sebesar 88,54 \%, aspek komunikasi terdiri dari kemudahan melalui program, kejelasan petunjuk penggunaan dan penggunaan bahasa memperoleh nilai sebesar $88,89 \%$, dan aspek desain teknik yang terdiri dari penggunaan huruf, penggunaan warna dan pemberian gambar memperoleh nilai sebesar $86,11 \%$. Secara keseluruhan, penilaian uji kelayakan kelompok kecil/terbatas terhadap media pembelajaran berbasis web mata pelajaran ipa terpadu di SMPN 10 Kendari sebesar 87,92 \%, sesuai dengan tabel 2.1. Skala 87,92 \% berada pada tingkat yang sangat layak, sehingga media pembelajaran berbasis web mata pelajaran ipa terpadu di SMPN 10 Kendari di interpretasikan sangat layak digunakan.

Hasil penilaian uji kelayakan kelompok besar/lebih luas media pembelajaran berbasis web mata pelajaran ipa terpadu di SMPN 10 Kendari yang melibatkan 29 ditinjau dari aspek efek strategi pembelajaran yang terdiri dari menambah pengetahuan mahasiswa, kemudahan penggunaan, meningkatkan rasa ingin tahu siswa, dan kejelasan materi yang di sajikan memperoleh nilai sebesar $86,21 \%$, aspek komunikasi terdiri dari kemudahan memulai program, kejelasan petuntuk penggunaan dan penggunaan bahasa memperoleh nilai sebesar $86,78 \%$, 
sedangkan dari aspek desain teknis yang terdiri dari penggunaan huruf, penggunaan warna dan pemberian gambar memperoleh nilai sebesar $86,03 \%$. Secara keseluruhan, penilaian uji kelayakan kelompok besar/kelompok lebih luas terhadap desain media pembelajaran berbasis web mata pelajaran ipa terpadu di SMPN 10 Kendari sebesar 86,03\%, sesuai dengan tabel 2.1. Skala $86,03 \%$ berada pada tingkat yang sangat layak, sehingga media pembelajaran berbasis web mata pelajaran ipa terpadu di SMPN 10 Kendari di interpretasikan sangat layak digunakan.

\section{KESIMPULAN}

Berdasarkan paparan hasil penelitian, simpulan penelitian ini adalah sebagai berikut:

a. Media pembelajaran berbasis web mata pelajaran ipa terpadu di SMPN 10 Kendari, setelah dilakukan uji kelayakan konten mendapat nilai sebesar $94,32 \%$, diinterpretasikan sangat layak digunakan.

b. Hasil penilaian validasi materi pada media pembelajaran berbasis web mata pelajaran ipa terpadu di SMPN 10 Kendari sebesar 94,44 \%, diinterprestasikan sangat layak digunakan.

c. Hasil penilaian uji kelayakan kelompok kecil/terbatas terhadap media pembelajaran berbasis web mata pelajaran ipa terpadu di SMPN 10 Kendari sebesar 87,92 \%, diinterpretasikan sangat layak digunakan.

d. Hasil penilaian uji kelayakan kelompok besar/kelompok lebih luas terhadap media pembelajaran berbasis web mata pelajaran ipa terpadu di SMPN 10 Kendari sebesar $86,03 \%$, diinterpretasikan sangat layak digunakan.

e. Secara keseluruhan Media pembelajaran berbasis web mata pelajaran ipa terpadu di SMPN 10 Kendari sangat layak digunakan dalam pembelajaran.

\section{DAFTAR PUSTAKA}

Arikunto, Suharsimi. 1996. Prosedur Penelitian Suatu Pendekatan Praktek. Jakarta: PT. Rineka Cipta.

Arsyad, Azhar. 2006. Media Pembelajaran, Jakarta.PT, Raja Grafindo Persada,

Daryanto, 2010. Media Pembelajaran. Bandung, Satu Nusa.

Hanick. Robert, Dkk 2002. Instructional media and technologies for learning. New Jersey. Prencite Hall. 
Iskandar, 2010, Metodologi penelitian pendidikan dan sosial (Kuantitatif dan Kualitatis), Gaung Persada Press, Jakarta.

Kristanto, Andri, 2004, Jaringan Syaraf Tiruan (Konsep Dasar, Algoritma, dan Aplikasinya), Gava Media, Yogyakarta.

Rusman, 2012. Belajar dan Pembelajaran Berbasis Komputer Mengembangkan Profesionalisme Guru Abad 21, Alfabeta, Bandung.

Sadiman, Arie. S, 2006. Media pendidikan: Pengertian, pengembangan dan pemanfaatan. Jakarta, PT. Raja Grafindo Persada.

Sanjaya, Wina 2008, Perencanaan dan Desain Sistem Pembelajaran, Kencana Prenada Media Group, Jakarta.

Sugiono, 2010, Metode Penelitian Kuantitatif, Kualitatif dan R\&D, Alfabeta, Bandung. 